\title{
Land-use Structure - Analysis on Example of Rural and Urban Communes in Poland and Ukraine ${ }^{* * *}$
}

\begin{abstract}
Intensive modernization of the cadastre has been implemented in Poland in recent years. During the modernization procedure, land use was updated as well. Obviously, such an update is also carried out on a regular basis, during individual surveying works associated with the real estate cadastre. The article presents an analysis of land-use changes on examples of urban and rural communes in Poland during the period of 2002-2015 (as well as the situation in this aspect in Ukraine).

During the analyzed period in Poland, there were two comprehensive modernizations of the cadastre carried out in the study area. The analysis covered two types of usable land: developed agricultural land $(B r)$ and residential areas $(B)$. These two particular types of land use were selected, as the applicable legal provisions in Poland regulating the principles for assigning land use to a specific group changed significantly. At the same time, radically different real estate tax rates are planned for these types of land use. The study also analyzes the changes in the communes' receipts from the taxes that are imposed on the owners of land due to the update of the cadastral survey related to the land-use changes.
\end{abstract}

Keywords: cadastre, land-use changes, developed agricultural land, residential areas, property tax

* Lviv National Agrarian University, Ukraine

** AGH University of Science and Technology, Faculty of Mining Surveying and Environmental Engineering, Krakow, Poland

*** This work has been done as a part of scientific research carried out in Department of Integrated Geodesy and Cartography 11.11.150.444 


\section{Introduction}

Each year, the Head Office of Land Surveying and Cartography is supplied with the specification of the land occupied by particular types of land use, together with a subdivision into the type of ownership or possession rights. It is prepared by all districts for individual cadastral units and jointly for the entire district. This formed the basis for the analysis of the changes in land use during the period of 2002-2015 in the territory of two cadastral units: Trzebinia (town - urban commune) and Trzebinia (rural area - rural commune). The selection of these particular cadastral units was dictated by the fact that the register of land and buildings in these areas was modernized twice during the analyzed period. The first modernization of the cadastre was carried out in 2005, followed by another in 2015 . The 2015 modernization was implemented as part of the national project called the Construction of Integrated Real Estate Information System (ZSIN) - Stage I, using funds from the European Union [1, 2, 14, 42].

Modernization of the register of land and buildings can be defined as entering the current situation that exists in the field into the database of the ICT system by the appropriate records as well as an adaptation of the existing data sets of the real estate cadastre stored in electronic form to the applicable provisions of the law contained in the relevant acts and regulations [9, 10, 15, 40, 41].

The analysis of the data will allow us to capture the trends of changes in the structure of land use and to assess the influence of the implemented modernization procedures on entering the appropriate land use into the cadastral database $[5,7,12$, $16,37]$. This results in notifying the tax authorities, which in turn leads to changes in the assessment of property tax imposed on land owners. Therefore, one of the effects of modernization is the changes that have occurred in the amount of the communal budget receipts [34].

In Ukraine, information about land resources is concentrated in the system of the state land cadastre [39]. For the last five years, it has been reforming, changing, and introducing geoinformatic technologies that help secure the accumulation, transparency, and availability of data.

This article aims to demonstrate the influence of the modernization of the cadastre on the increased financial benefits to the communes as beneficiaries of the real estate tax receipts.

\section{Materials and Methods}

\subsection{Land Use Change in Poland}

The data underlying the analysis in Poland for the cadastral units of Trzebinia (town - urban commune) and Trzebinia (rural area - rural commune) is briefly summarized in Table 1. 
Table 1. Summary of the land-use areas

\begin{tabular}{|c|c|c|c|c|}
\hline \multirow{5}{*}{ Year } & \multicolumn{4}{|c|}{ Type of cadastral unit } \\
\hline & \multicolumn{2}{|c|}{ urban commune } & \multicolumn{2}{|c|}{ rural commune } \\
\hline & \multicolumn{2}{|c|}{ type of land use } & \multicolumn{2}{|c|}{ type of land use } \\
\hline & $\begin{array}{c}\text { developed } \\
\text { agricultural land } \\
\qquad(\mathrm{Br})\end{array}$ & $\begin{array}{c}\text { residential areas } \\
(B)\end{array}$ & $\begin{array}{l}\text { developed } \\
\text { agricultural land } \\
\qquad(B r)\end{array}$ & $\begin{array}{l}\text { residential } \\
\text { areas } \\
(B)\end{array}$ \\
\hline & [ha] & [ha] & [ha] & [ha] \\
\hline 2002 & 137 & 78 & 174 & 10 \\
\hline 2003 & 138 & 76 & 174 & 10 \\
\hline 2004 & 129 & 90 & 167 & 19 \\
\hline 2005 & 3 & 199 & 20 & 194 \\
\hline 2006 & 3 & 199 & 21 & 196 \\
\hline 2007 & 3 & 186 & 23 & 200 \\
\hline 2008 & 3 & 189 & 25 & 202 \\
\hline 2009 & 4 & 200 & 25 & 198 \\
\hline 2010 & 4 & 203 & 29 & 205 \\
\hline 2011 & 4 & 206 & 28 & 208 \\
\hline 2012 & 4 & 209 & 28 & 212 \\
\hline 2013 & 4 & 211 & 28 & 216 \\
\hline 2014 & 3 & 216 & 27 & 219 \\
\hline 2015 & 20 & 286 & 30 & 260 \\
\hline
\end{tabular}

Due to the volume of this study, analysis of the land-use changes has been limited to residential areas of two types: developed agricultural land $(B r)$, which includes residential and production areas used for farming; and residential areas $(B)$, which is land serving exclusively to satisfy the housing needs (without agricultural production). This choice is also dictated by the analysis performed to specify the financial benefits for the communes after the modernization of the cadastre. It should be emphasized at this point that land use $B$ has a much-higher tax rate per unit of the area compared to land use $\mathrm{Br}$. Bar charts (Figs. 1 and 2) illustrate the data contained in Table 1 referring to the urban commune.

When analyzing the bar charts related to the urban commune (Figs. 1 and 2), it is evident that the changes in the areas of land use $B r$ and land use $B$ presented in these bar charts are interrelated. It can be noticed that each modernization of the cadastre (in 2005 and again in 2015) significantly affected the value of the area in each land use in the real estate cadastre. 


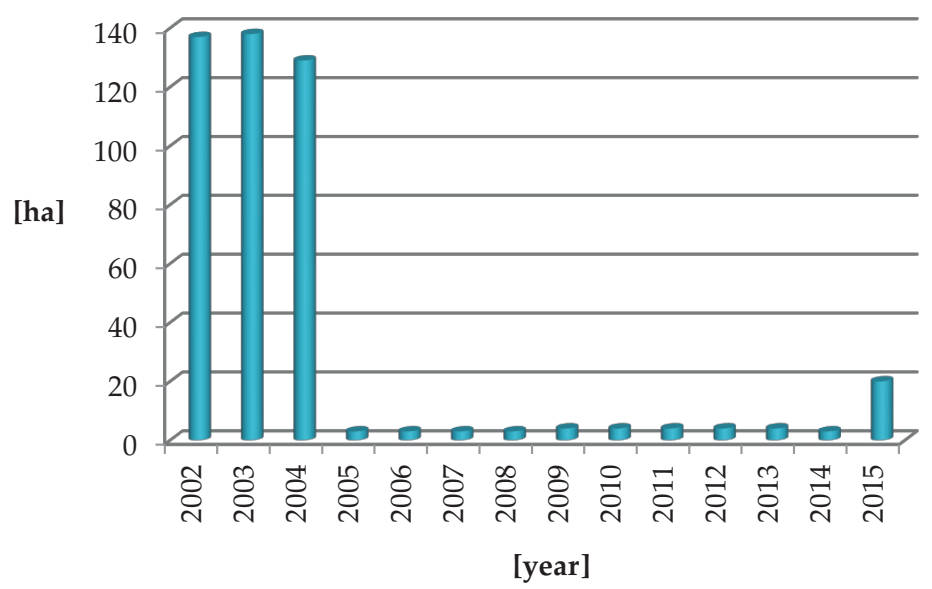

Fig. 1. Changes in $(\mathrm{Br})$ area for urban commune

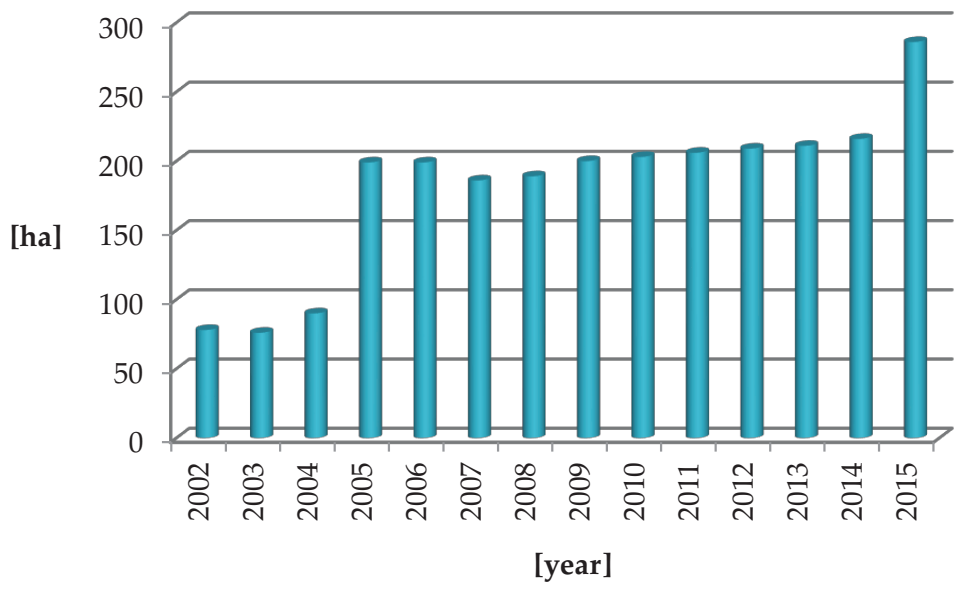

Fig. 2. Changes in $(B)$ area for urban commune

Bar charts (Figs. 3 and 4) illustrate the data contained in Table 1 referring to the rural commune.

Similar as it with the urban community (and also in the case of the rural area), there is a close interaction of the data presented in the bar charts (Figs. 3 and 4). The value of the area of each land use was mainly influenced by the modernizations of the cadastre implemented in 2005 and 2015. Both in the urban and rural areas, it can be observed that developed agricultural land $(B r)$ was substantially transformed into residential areas $(B)$, especially during the modernization of the cadastre in 2005. 


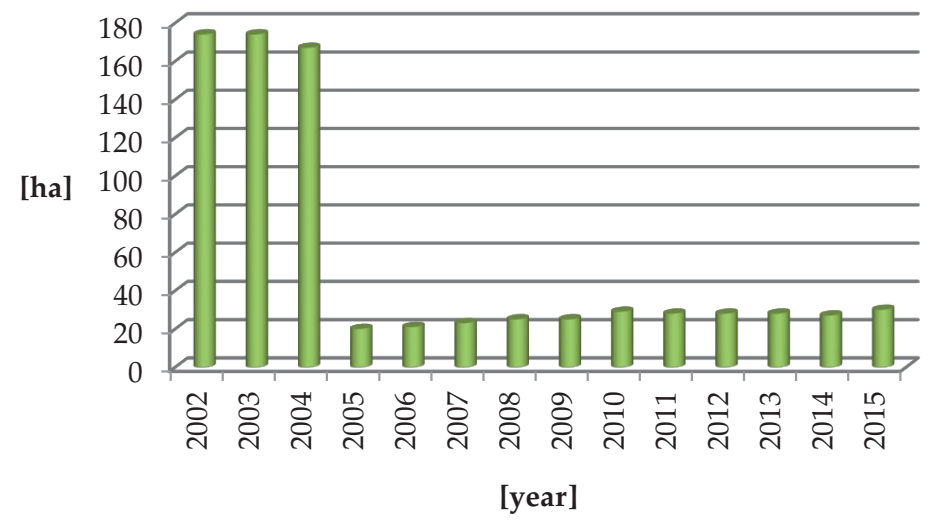

Fig. 3. Changes in $(\mathrm{Br})$ area for rural commune

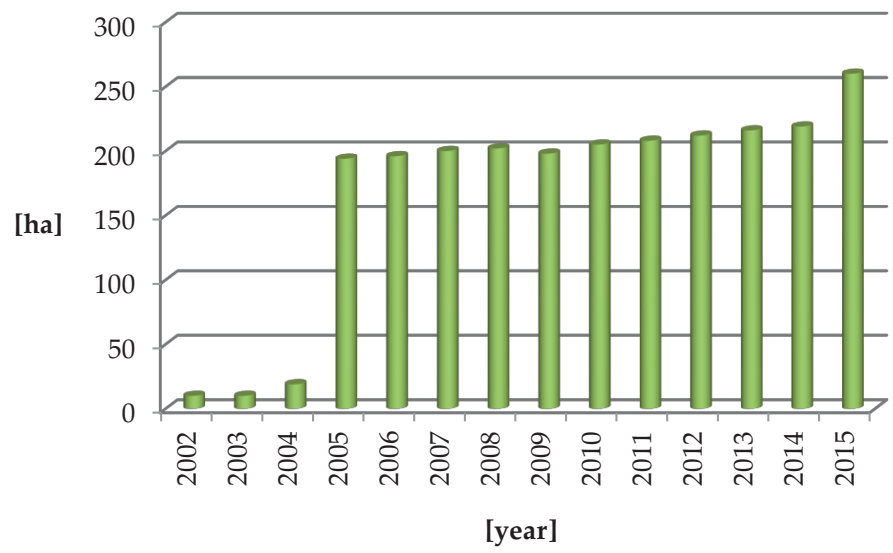

Fig. 4. Changes in $(B)$ area for rural commune

\subsection{Land-Use Change in Ukraine}

The system of land parcel registration is made up of two stages. The first stage expects the registration of a land parcel in the land register of the system of the state land cadaster; and in the second stage, the land parcel is listed in the registry of property rights for real estate and its encumbrances, registering the real estate located on the land parcel. Thus, such a procedure secures the formation of common information about estate objects. Information about land parcels is additionally fixed in the national cadastre map.

The system of state land cadastre records all lands of Ukraine with a total area of 60.350 million ha, including 42.742 million ha of agricultural lands. The second-largest category is comprised of forests in rural area (i.e., 17.5\%), and the third one - the territory of residential and public buildings in urban areas (i.e., 23.4\%) (Fig. 5). 


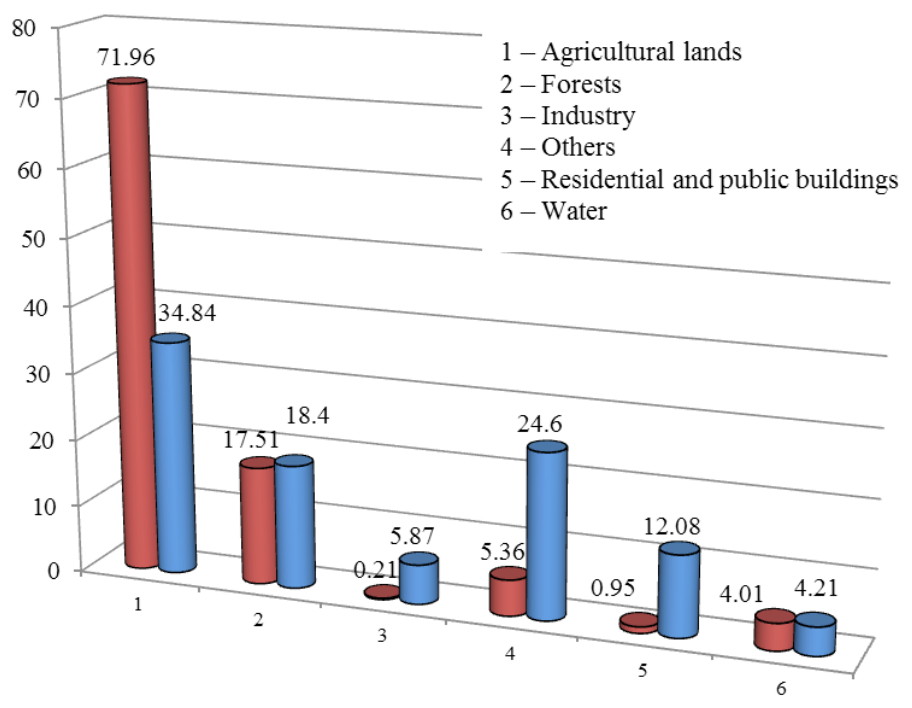

$\square$ Rural area $\square$ Towns

Fig. 5. Distribution of lands according to their intended use

The distribution of lands according to the forms of ownership is as follows: state-owned - 28.9 million ha of land; private -31.4 million ha; collective - 0.06 million ha; and communal - 0.013 million ha. This is presented in Figure 6 in terms of rural and urban areas.

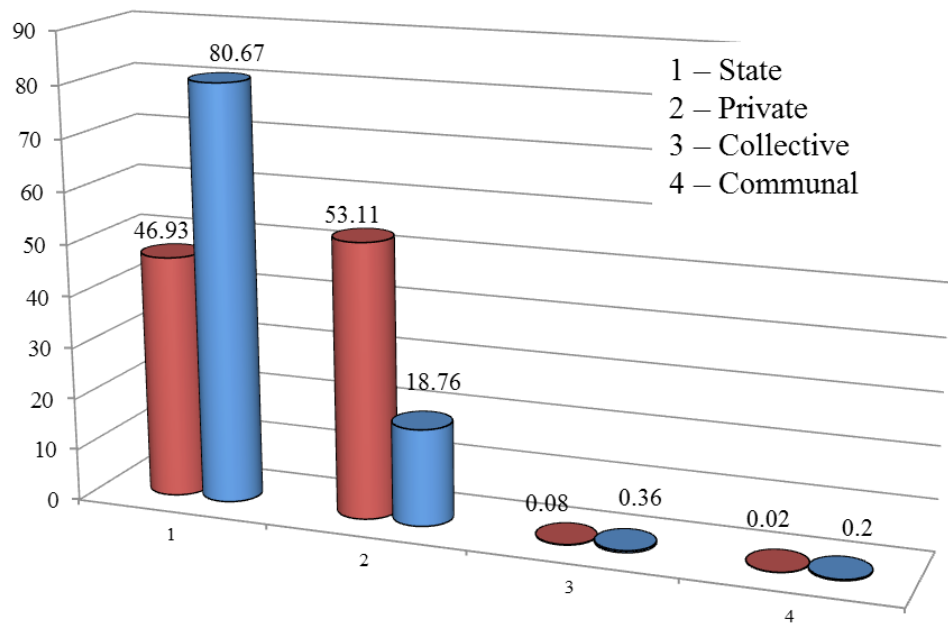

$\square$ Rural area $\square$ Towns

Fig. 6. Distribution of land according to forms of ownership 
One can see that the lands of private ownership prevail in rural areas while state-owned lands prevail in urban areas.

In Ukraine, landowners and land users are represented both by natural and legal persons. Nowadays, Ukraine counts 15,854,195 owners of land parcels, including 1,395,480 legal persons (8.8\%). According to the forms of ownership, $90 \%$ of them possess lands, $7 \%$ have state-owned lands at their disposal, and 3\% - of a communal nature. The number of registered landowners and land users makes $63 \%$ of the total number mentioned in the land cadastre.

Currently, there are 16,661,051 registered land parcels with a total area of $4,181,212,776$ ha, accounting $69 \%$ of the territory of Ukraine. Among them, 3,485,630 land parcels are registered in the state registry of property rights for real estate, accounting for $13 \%$ of all lands. However, just $22.6 \%$ of state-owned lands are registered in the state land cadastre.

The total number of land-tax payers comes to 7,337,191 people, including $98 \%$ of natural persons. Forty-six percent of them are registered in the state land cadaster; among them, only $31 \%$ are landowners [33].

\section{Discussion}

Analyses of land use in a historical aspect have been carried out in numerous studies, including $[11,19,26,38]$. However, the historical analyses carried out with the use of archival maps cannot replace the data derived from the current modernization of the cadastre $[18,20,21,22,30]$. In order to illustrate the trends of the changes regarding the developed agricultural land $(B r)$ and residential areas $(B)$, annual changes in their areas (expressed in hectares) as well as the percentage of changes in the areas of the analyzed land use were calculated. The land-use changes analyzed in this paper were compared to the year 2002, which was the initial year of the analyses being carried out. These are illustrated in Table 2.

Table 2. Annual changes in land-use areas

\begin{tabular}{|c|c|c|c|c|c|c|c|c|}
\hline \multirow{4}{*}{ Year } & \multicolumn{8}{|c|}{ Annual changes in the land area } \\
\hline & \multicolumn{4}{|c|}{ urban commune } & \multicolumn{4}{|c|}{ rural commune } \\
\hline & \multicolumn{2}{|c|}{$\begin{array}{c}\text { developed } \\
\text { agricultural land } \\
\qquad(B r)\end{array}$} & \multicolumn{2}{|c|}{$\begin{array}{l}\text { residential } \\
\text { areas } \\
(B)\end{array}$} & \multicolumn{2}{|c|}{$\begin{array}{l}\text { developed } \\
\text { agricultural land } \\
\qquad(B r)\end{array}$} & \multicolumn{2}{|c|}{$\begin{array}{l}\text { residential } \\
\text { areas } \\
(B)\end{array}$} \\
\hline & [ha] & {$[\%]$} & [ha] & {$[\%]$} & [ha] & {$[\%]$} & [ha] & {$[\%]$} \\
\hline 1 & 2 & 3 & 4 & 5 & 6 & 7 & 8 & 9 \\
\hline 2002 & 0 & 0.00 & 0 & 0.00 & 0 & 0.00 & 0 & 0.00 \\
\hline 2003 & +1 & $+0,73$ & -2 & -2.56 & 0 & 0.00 & 0 & 0.00 \\
\hline 2004 & -9 & -6.52 & +14 & +18.42 & -7 & -4.02 & +9 & +90.00 \\
\hline
\end{tabular}


Table 2. cont

\begin{tabular}{||c|c|c|c|c|c|c|c|c||}
\hline 1 & 2 & 3 & 4 & 5 & 6 & 7 & 8 & 9 \\
\hline \hline 2005 & -126 & -97.67 & +109 & +121.11 & -147 & -88.02 & +175 & +921.05 \\
\hline 2006 & 0 & 0.00 & 0 & 0.00 & +1 & +5.00 & +2 & +1.03 \\
\hline 2007 & 0 & 0.00 & -13 & -6.53 & +2 & +9.52 & +4 & +2.04 \\
\hline 2008 & 0 & 0.00 & +3 & +1.61 & +2 & +8.70 & +2 & +1.00 \\
\hline 2009 & +1 & +33.33 & +11 & +5.82 & 0 & 0.00 & -4 & -1.98 \\
\hline 2010 & 0 & 0.00 & +3 & +1.50 & +4 & +16.00 & +7 & +3.54 \\
\hline 2011 & 0 & 0.00 & +3 & +1.48 & -1 & -3.45 & +3 & +1.46 \\
\hline 2012 & 0 & 0.00 & +3 & +1.46 & 0 & 0.00 & +4 & +1.92 \\
\hline 2013 & 0 & 0.00 & +2 & +0.96 & 0 & 0.00 & +4 & +1.89 \\
\hline 2014 & -1 & -25.00 & +5 & +2.37 & -1 & -3.57 & +3 & +1.39 \\
\hline 2015 & +17 & +566.67 & +70 & +32.41 & +3 & +11.11 & +41 & +18.72 \\
\hline
\end{tabular}

The results contained in Table 2 are illustrated in hectares in the following graphs (Figs. 7-10) and expressed as a percentages.

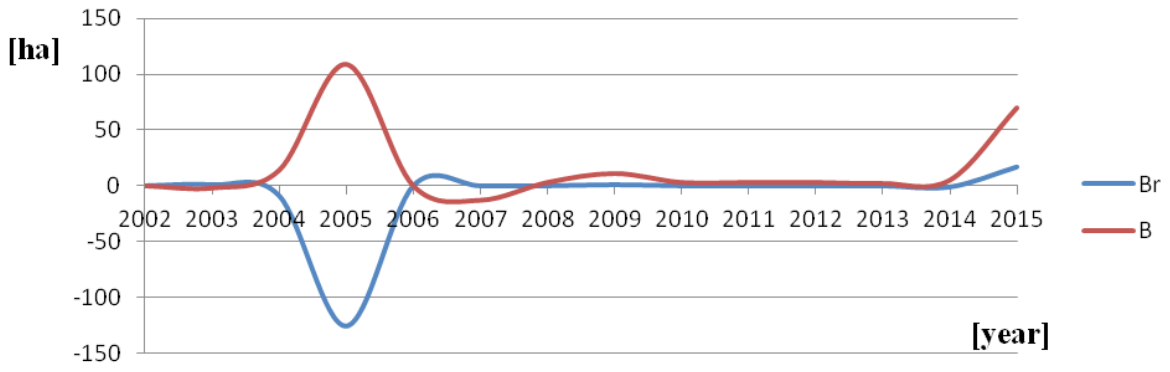

Fig. 7. Surface area during years 2002-2015 for urban commune

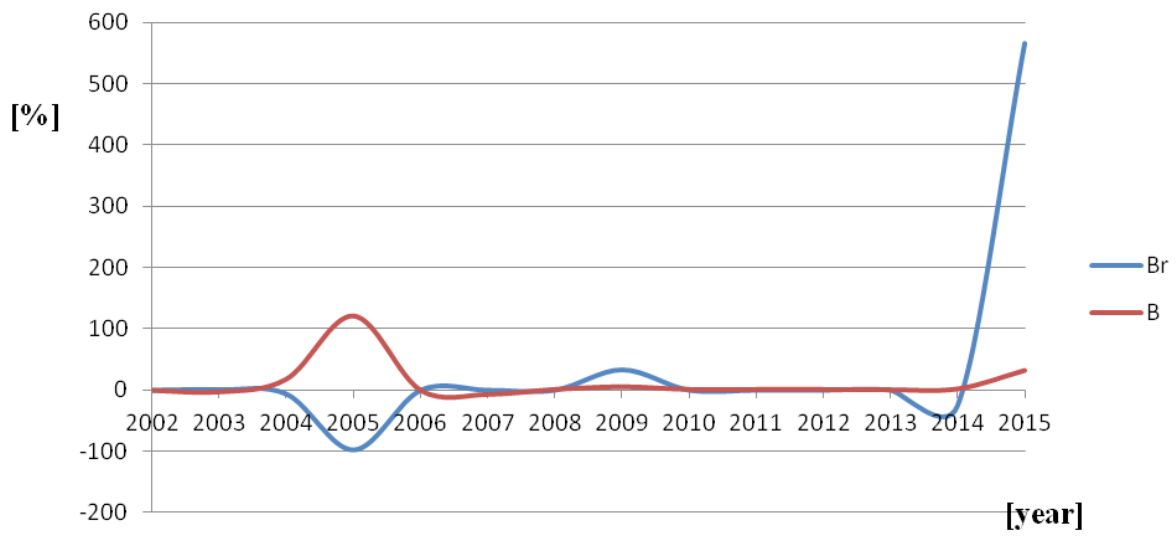

Fig. 8. Surface area during years 2002-2015 for urban commune 


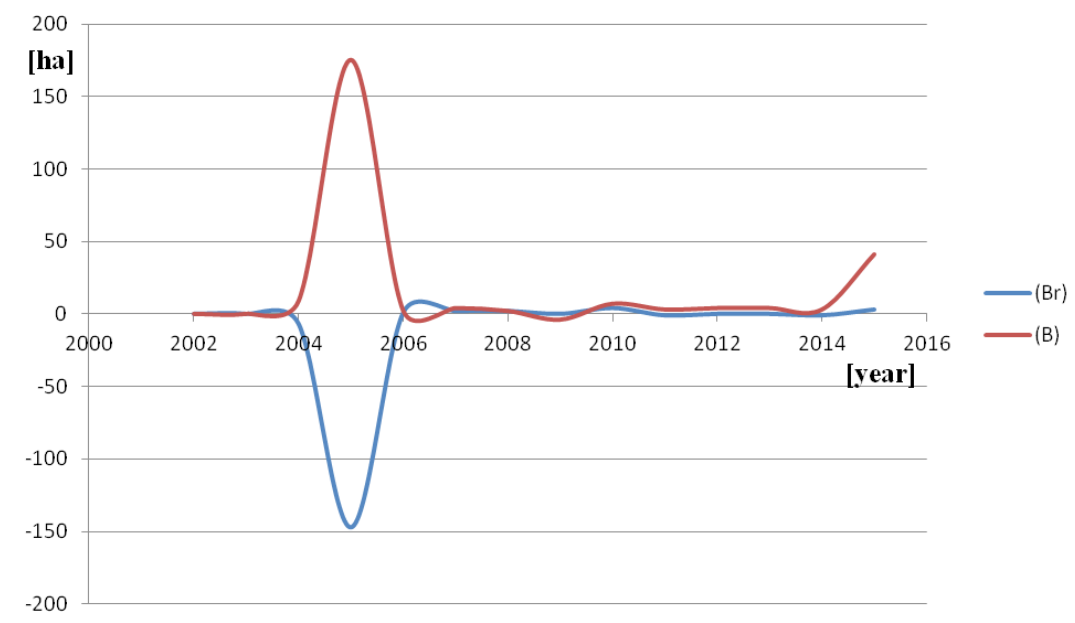

Fig. 9. Surface area during years 2002-2015 for rural commune

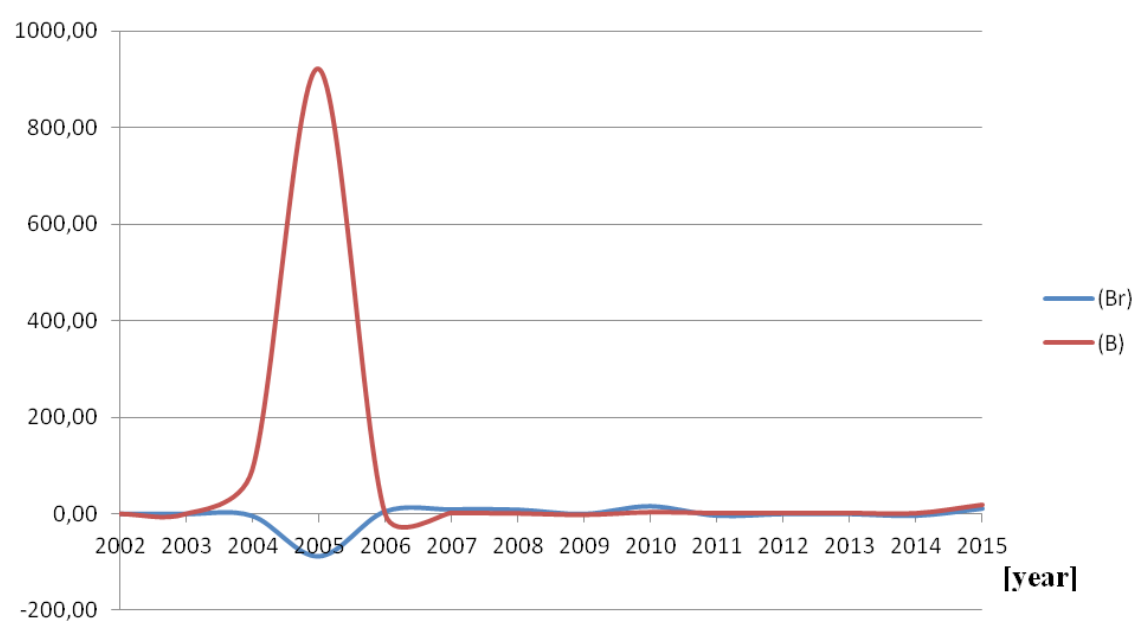

Fig. 10. Surface area during years 2002-2015 for rural commune

The contents of the graphs demonstrate that the changes that took place in the developed agricultural land $(B r)$ and residential areas $(B)$ are closely related. It can be observed that the greatest changes in the surface areas of these two types of land occurred between 2005 and 2015, when the modernization of the cadastre was carried out. Figures 7 and 9 illustrate that, as a result of the modernization implemented in 2005, the area in the residential areas $(B)$ increased by more than 100 hectares in urban areas and by more than 150 hectares in rural areas. On the other hand, the surface area of the developed agricultural land $(\mathrm{Br})$ decreased by similar values at the same time, which can be noticed in the graphs. It should be emphasized that an area of 100 ha is about $3.5 \%$ of the total area of the cadastral unit, so the change is 
significant. Therefore, it can be concluded that the developed agricultural land $(\mathrm{Br})$ was converted into residential areas $(B)$. This change was related to the application of the current legal provisions, which clarify the principles of converting developed agricultural land $(B r)$ into residential areas $(B)$.

These two graphs (Figs. 7 and 9) also depict an increase in the surface area of both types of land use ( $\mathrm{Br}$ and $\mathrm{B}$ ) in 2015 - after the next modernization of the cadastre. During the years between the modernizations (i.e., 2005-2014), the area of the developed agricultural land $(\mathrm{Br})$ and residential areas $(B)$ remained constant.

The next stage of this study includes a presentation of a simplified analysis of the changes in tax rates in the urban and rural communes. The simplification of the analysis involves the reference only to the taxes on developed rural areas $(\mathrm{Br})$ and on residential areas $(B)$ as well as the adoption of the same tax rate for both types of land for the period of 2002-2015. Pursuant to the applicable laws and the resolution of the Communal Council, the following mean values of the annual tax rates were adopted for the analysis:

- 201.56 PLN per hectare of the developed agricultural land (Br),

- 2,900.00 PLN per hectare of the residential areas (B).

Tables 3 and 4 present the approximate values of the taxes on the developed agricultural land and residential areas, calculated for the aforementioned tax rates for the period of 2002-2015. The data contained in Tables 3 and 4 is illustrated in the bar charts (Figs. 11 and 12).

Table 3. Values of taxes on $(B r)$ and $(B)$ for urban commune

\begin{tabular}{||c|c|c|c|c|c|c||}
\hline \multirow{3}{*}{ Year } & \multicolumn{7}{|c|}{\begin{tabular}{c} 
Values of taxes - urban commune \\
\cline { 2 - 7 }
\end{tabular}} & $\begin{array}{c}\text { developed } \\
\text { agricultural land } \\
(\mathrm{Br})\end{array}$ & tax value & $\begin{array}{c}\text { changes in } \\
\text { the values of } \\
\text { taxes }\end{array}$ & $\begin{array}{c}\text { residential } \\
\text { areas } \\
(B)\end{array}$ & tax value & $\begin{array}{c}\text { changes in } \\
\text { the values of } \\
\text { taxes }\end{array}$ \\
\cline { 2 - 7 } & {$[\mathrm{ha}]$} & {$[\mathrm{PLN}]$} & {$[\%]$} & {$[\mathrm{ha}]$} & {$[\mathrm{PLN}]$} & {$[\%]$} \\
\hline \hline 2002 & 137 & 27,614 & 0.00 & 78 & 226,200 & 0.00 \\
\hline 2003 & 138 & 27,815 & $+0,73$ & 76 & 220,400 & -2.56 \\
\hline 2004 & 129 & 26,001 & -6.52 & 90 & 261,000 & +18.42 \\
\hline 2005 & 3 & 604 & -97.67 & 199 & 577,100 & +121.11 \\
\hline 2006 & 3 & 604 & 0.00 & 199 & 577,100 & 0.00 \\
\hline 2007 & 3 & 604 & 0.00 & 186 & 539,400 & -6.53 \\
\hline 2008 & 3 & 604 & 0.00 & 189 & 548,100 & +1.61 \\
\hline 2009 & 4 & 806 & +33.33 & 200 & 580,000 & +5.82 \\
\hline 2010 & 4 & 806 & 0.00 & 203 & 588,700 & +1.50 \\
\hline 2011 & 4 & 806 & 0.00 & 206 & 597,400 & +1.48 \\
\hline 2012 & 4 & 806 & 0.00 & 209 & 606,100 & +1.46 \\
\hline 2013 & 4 & 806 & 0.00 & 211 & 611,900 & +0.96 \\
\hline 2014 & 3 & 604 & -25.00 & 216 & 626,400 & +2.37 \\
\hline 2015 & 20 & 4031 & +566.67 & 286 & 829,400 & +32.41 \\
\hline
\end{tabular}


Table 4. Values of taxes on $(B r)$ and $(B)$ for rural commune

\begin{tabular}{|c|c|c|c|c|c|c|}
\hline \multirow{3}{*}{ Year } & \multicolumn{6}{|c|}{ Values of taxes - rural commune } \\
\hline & $\begin{array}{c}\text { developed } \\
\text { agricultural land } \\
\qquad(B r)\end{array}$ & tax value & $\begin{array}{l}\text { changes in } \\
\text { the values of } \\
\text { taxes }\end{array}$ & $\begin{array}{l}\text { residential } \\
\text { areas } \\
\text { (B) }\end{array}$ & tax value & $\begin{array}{l}\text { changes in } \\
\text { the values of } \\
\text { taxes }\end{array}$ \\
\hline & [ha] & {$[\mathrm{PLN}]$} & [\%] & [ha] & {$[\mathrm{PLN}]$} & {$[\%]$} \\
\hline 2002 & 174 & 35,071 & 0.00 & 10 & 29,000 & 0.00 \\
\hline 2003 & 174 & 35,071 & 0.00 & 10 & 29,000 & 0.00 \\
\hline 2004 & 167 & 33,661 & -4.02 & 19 & 55,100 & +90.00 \\
\hline 2005 & 20 & 4031 & -88.02 & 194 & 562,600 & +921.05 \\
\hline 2006 & 21 & 4232 & +5.00 & 196 & 568,400 & +1.03 \\
\hline 2007 & 23 & 4635 & +9.52 & 200 & 580,000 & +2.04 \\
\hline 2008 & 25 & 5039 & +8.70 & 202 & 585,800 & +1.00 \\
\hline 2009 & 25 & 5039 & 0.00 & 198 & 574,200 & -1.98 \\
\hline 2010 & 29 & 5845 & +16.00 & 205 & 594,500 & +3.54 \\
\hline 2011 & 28 & 5643 & -3.45 & 208 & 603,200 & +1.46 \\
\hline 2012 & 28 & 5643 & 0.00 & 212 & 614,800 & +1.92 \\
\hline 2013 & 28 & 5643 & 0.00 & 216 & 626,400 & +1.89 \\
\hline 2014 & 27 & 5442 & -3.57 & 219 & 635,100 & +1.39 \\
\hline 2015 & 30 & 6046 & +11.11 & 260 & 754,000 & +18.72 \\
\hline
\end{tabular}

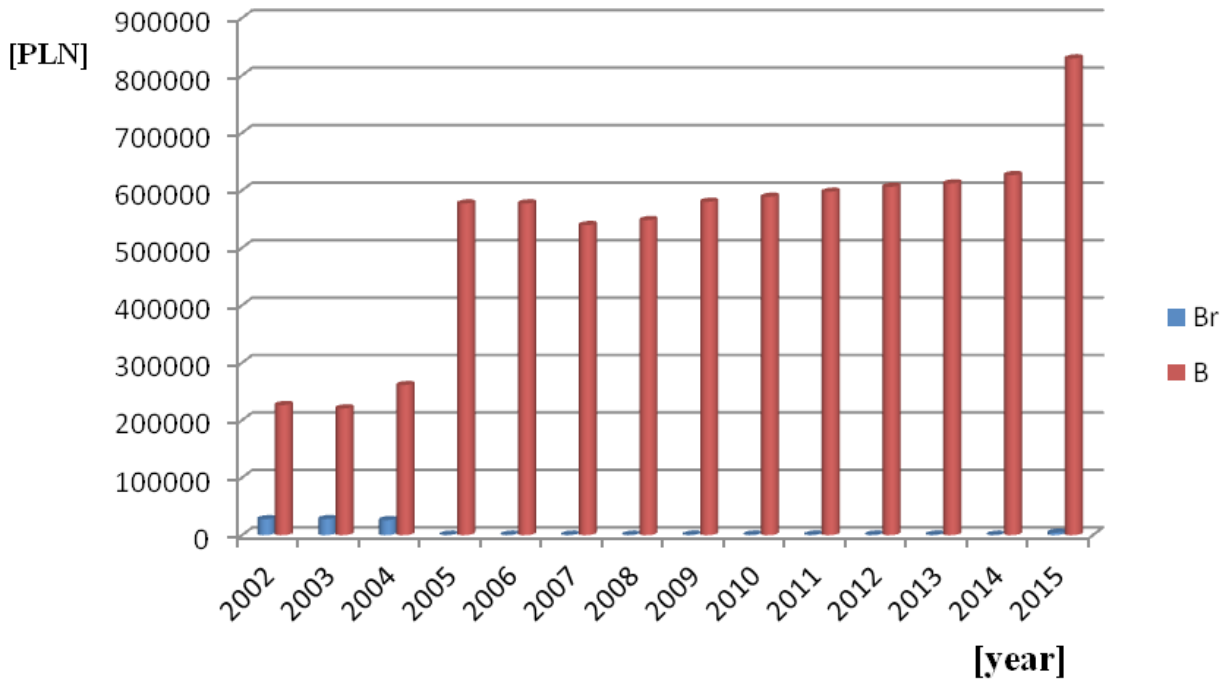

Fig. 11. Changes in values of taxes on $(B r)$ and $(B)$ for urban commune 


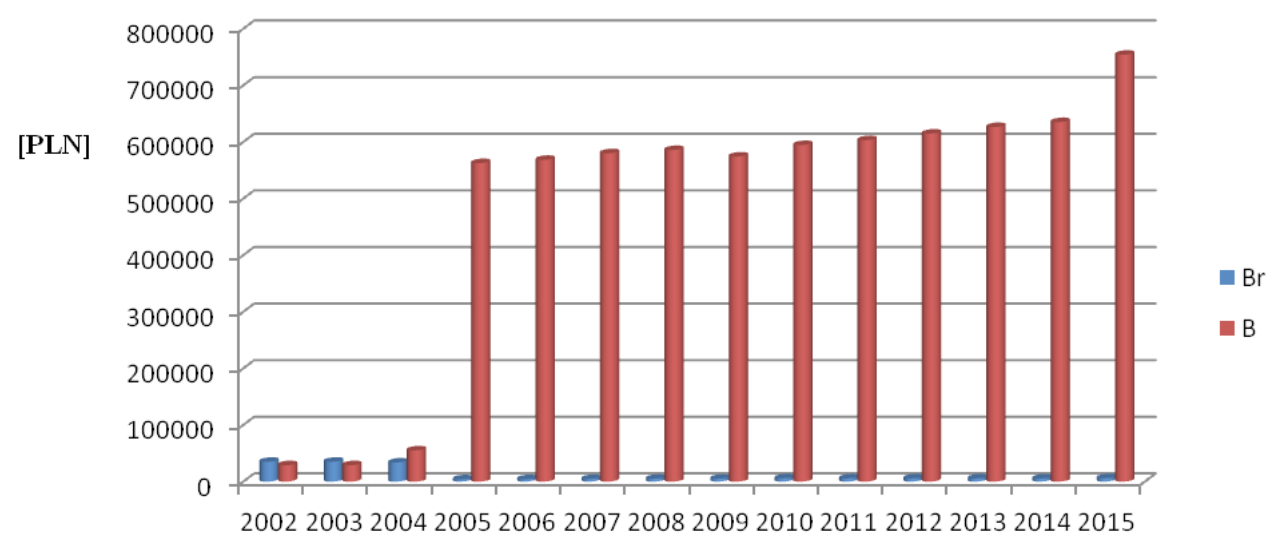

[year]

Fig. 12. Changes in values of taxes on $(B r)$ and $(B)$ for rural commune

An analysis of the statistical data proves that, in Ukraine, tax revenues from land fee increased each year [35]. Thus, in 2016, revenues from the tax increased 4.1 times as compared to 2006 and resulted in 12.6 billion UAH. However, during the same period, the share of land fee increased by just $2.1 \%$ in local budget revenue (Fig. 13).

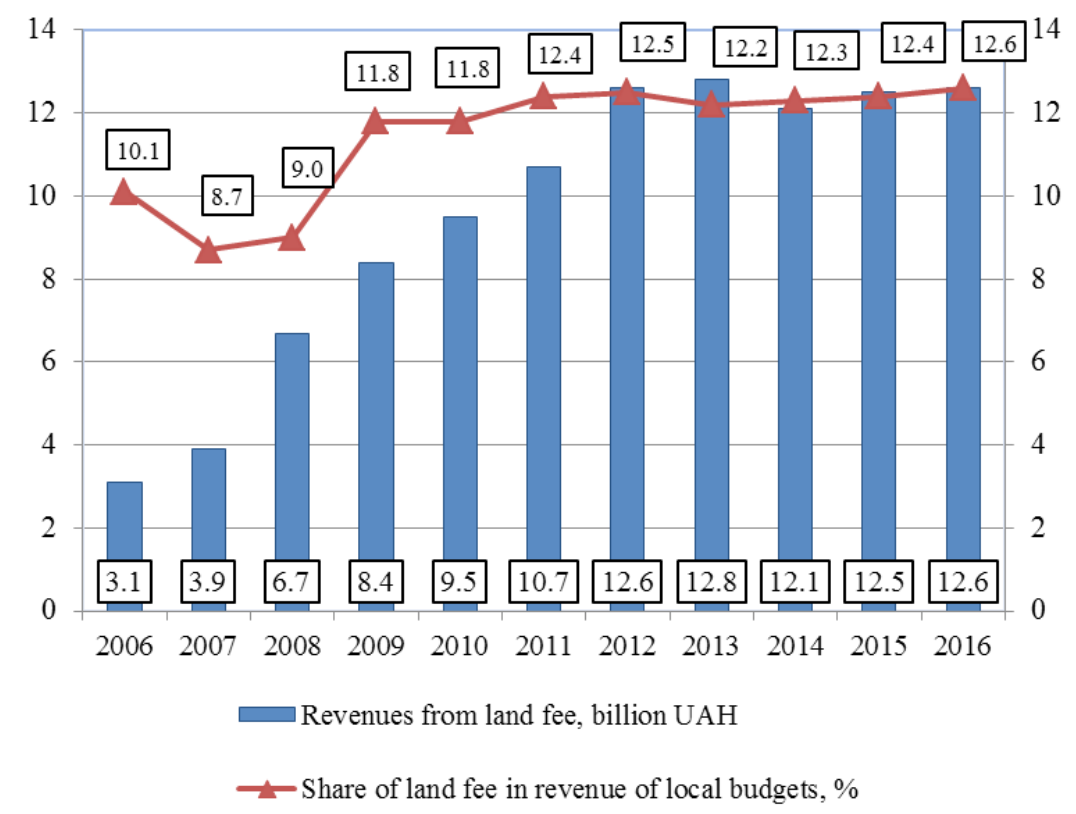

Fig. 13. Dynamics of revenues from land fee from 2006-2016 
In spite of the fact that the land fee is the second-largest source of revenue for local budgets, the average value of the obligatory payment is not large in local budgets. Its share did not changed during the mentioned period, accounting for $12.2 \%$. International practice proves that the share of land tax (which can be charged separately or as part of a real estate tax) is considerably larger in the revenue of local budgets abroad than it is in Ukraine, accounting for between 15\% and 45\% [8]. In Ukraine, there is some progress in the direction. In 2015, changes to the tax code of Ukraine as to the decentralization of budget revenues will result in the fact that land tax will be left at the local level and be accompanied by a newly introduced real estate tax. Such changes support the fiscal independence of local authorities concerning local taxes and fees, particularly by providing the right to define the tax rates and privileges independently. However, the value of the revenue will depend on the tax policy and number of registered land parcels in the system of registry of the property rights for real estate. Many landowners pay taxes without an official registration (for land, distributed before the approval of the current system of registration), because tax payments are often considered as an indirect confirmation of ownership rights.

\section{Summary}

Both bar charts presenting the values of taxes on the developed agricultural land $(B r)$ and residential areas $(B)$ in the urban and rural communes demonstrate that the conversion of the developed agricultural land $(B r)$ into residential areas $(B)$ has had a great influence on the value of the receipts from taxation. The amount of the taxes increased significantly each year after the modernization of the cadastre, both in 2005 and 2015. The revenue of the commune is generated mainly by the residential areas $(B)$, whereas the increase in the developed agricultural land $(\mathrm{Br})$ does not generate any significant receipts.

Therefore, the conducted modernization of the cadastre results in some benefits, as exemplified by the authors of numerous scientific studies, including [6, 13, 31, 32, 43].

The benefits of the modernization can be grouped into three main areas:

- the modernization of the cadastre allows officials self-government officials to meet the legal requirements, so that the district governor runs the database of the real estate cadastre according to the requirements of updatedness validity and compliance with the provisions of law;

- the modernization of the cadastre allows government officials to regulate the ownership rights within the modernized cadastral districts and improves the quality of the cadastral data. These objectives can also be met in the processes of the reparcelling and exchange of land, implemented in Poland on a large scale $[27,28]$.

- the modernization of the cadastre also brings tangible financial benefits for the communes; the beneficiaries of the taxation of land according to its actual land use. 
The analyzed bar charts and graphs demonstrate that the individual surveying reports, prepared between the modernizations of the cadastre, do not entirely fulfill the role of updating the database of the real estate cadastre, although they are frequently associated with land-use changes. The quantitative status of the residential areas $(B)$ between modernizations remained at a similar level. Only the comprehensive modernizations of the real estate cadastre carried out in 2005 and 2015 produced tangible financial results. It is necessary to introduce transparent and stable laws related to the real estate cadastre [7, 40, 20, 28, 33]. Frequent changes to the provisions of law are especially dangerous; obviously, they are necessary [6, 27, 29] as long as they do not change the previous principles of running the cadaster (which, unfortunately, we largely must deal with in Poland).

Thus, after the introduction of the changes to the tax code of Ukraine, the land fee has the status of a local tax and is part of the property tax. Analysis of the statistical data from the past few years confirms the positive dynamics of revenues from the land fee, supported by an improvement in the administration of the tax charging and recording of land parcel owners in the land cadastre. To authorize levying the tax on its citizens, it is necessary for the government to provide information on land parcels and real estate in the registry of property rights for real estate.

\section{References}

[1] Aien A., Rajabifard A., Kalantari M., Shojaei D.: Integrating Legal and Physical Dimensions of Urban Environments. ISPRS International Journal of Geo-Information, vol. 4, Issue 3, 2015, pp. 1442-1479.

[2] Akińcza M., Bieda A., Buśko M., Hannibal H., Hanus P., Hycner R., Krzyżek R., Kwartnik-Pruc A., Łuczyński R., Przewięźlikowska A.: Aktualne problemy katastru w Polsce. Oficyna Wydawnicza Politechniki Warszawskiej, Warszawa 2015.

[3] Alemie B.K., Bennett R.M., Zevenbergen J.: Evolving urban cadastres in Ethiopia: The impacts on urban land governance. Land Use Policy, vol. 42, 2015, pp. 695-705.

[4] Balawejder M., Buśko M., Cellmer R., Juchniewicz-Piotrowska K., Leń P., Mika M., Szczepankowska K., Wójciak E., Wójcik-Leń J., Źróbek S.: Aktualne problemy gospodarki nieruchomościami w Polsce na tle przemian organizacyjno-prawnych. Wyższa Szkoła Inżynieryjno-Ekonomiczna, 2015.

[5] Basiouka S., Potsiou C., Bakogiannis E.: OpenStreetMap for cadastral purposes: an application using VGI for official processes in urban areas. Survey Review, vol. 47, Issue 344, 2015, pp. 333-341.

[6] Bennett R.M., Alemie B.K.: Fit-for-purpose land administration: lessons from urban and rural Ethiopia. Survey Review, vol. 47, Issue 346, 2016, pp. 11-20.

[7] Bieda A., Hanus P.: Real Estate Boundaries on Maps for Projects. Geomatics and Environmental Engineering, vol. 4, no. 3, 2010, pp. 13-18. 
[8] Bird R., Slack E.: Land and property taxation in 25 countries: a comparative review. CESifo DICE Report, vol. 3, 2005, pp. 34-42.

[9] Brown G., Raymond C.M.: Methods for identifying land use conflict potential using participatory mapping. Landscape and Urban Planning, vol. 122, 2014, pp. 196-208.

[10] Buśko M., Bydłosz J., Dawidowicz A., Gross M., Kwartnik-Pruc A., Pietrzak L., Przewięźlikowska A., Trzcińska S., Źróbek-Różańska A., Źróbek R.: Modern systems of land administration and real estate management. Croatian Information Technology Society, GIS Forum; University of Warmia and Mazury, University of Silesia, Croatia, Olsztyn, Katowice 2014.

[11] Buśko M., Meusz A. Current status of real estate cadastre in Poland with reference to historical conditions of different regions of the country. [in:] $9^{\text {th }}$ ICEE: the $9^{\text {th }}$ International Conference Environmental Engineering: May 22-23, 2014, Vilnius, Lithuania: selected papers, Vilnius Gediminas Technical University Press Technika, Vilnius, DOI: 10.3846/enviro.2014.196. [on-line:] http:// leidykla.vgtu.lt/conferences/ENVIRO_2014/Abstracts/5/196.html [access: 1.03.2017].

[12] Buśko M., Przewięźlikowska A.: Analysis of legal regulations concerning the division of a building lot, with a building on it, in view of geodesic and building regulations. Geomatics and Environmental Engineering, vol. 3, no. 4, 2009, pp. 23-31.

[13] Buśko M., Przewięźlikowska A.: Application of the GEO-INFO GIS for modernization of the cadastre. Geomatics and Environmental Engineering, vol. 7, no. 4, 2013, pp. 17-29.

[14] Cagdas V., Stubkjaer E.: Core immovable property vocabulary for European linked land administration. Survey Review, vol. 47, Issue 340, 2015, pp. 49-60.

[15] Dawidowicz A., Źróbek R.: Analysis of concepts of cadastral system technological development. [in:] $9^{\text {th }}$ ICEE: the $9^{\text {th }}$ International Conference Environmental Engineering: May 22-23, 2014, Vilnius, Lithuania: selected papers, Vilnius Gediminas Technical University Press Technika, Vilnius, [on-line:] http:// dx.doi.org/10.3846/enviro.2014.201 [access: 1.03.2017].

[16] Demir O., Uzun B., Coruhlu Y.E.: Progress of cost recovery on cadastre based on land management implementation in Turkey. Survey Review, vol. 47, Issue 340, 2015, pp. 36-48.

[17] Doner F.. Evaluation of cadastre renovation studies in Turkey. Survey Review, vol. 47, Issue 341, 2015, pp. 141-152.

[18] Eliseev I.N., Hernik J., Noszczyk T.: Zmiana przeznaczenia gruntów rolnych na cele nierolnicze w Rosji i Polsce. Acta Scientiarum Polonorum. Formatio Circumiectus, vol. 13(4), 2014, pp. 55-64.

[19] Fuchs R., Verburg P.H., Clevers J.G.P.W., Herold M.: The potential of old maps and encyclopaedias for reconstructing historic European land cover/use change. Applied Geography, vol. 59, 2015, pp. 43-55.

[20] Gopikrishnan T., Ramakrishnan S.S.: Projection Analysis for Cadastral Mapping. Boletim de Ciencias Geodesicas, vol. 19, Issue 4, 2013, pp. 729-745. 
[21] Harvey F.: The Power of Mapping: Considering Discrepancies of Polish Cadastral Mapping. Annals of the Association of American Geographers, vol. 103, Issue 4, 2013, pp. 824-843.

[22] Hendrych J., Storm V., Pacini N.: The Value of an 1827 Cadastre Map in the Rehabilitation of Ecosystem Services in the Kremze Basin, Czech Republic. Landscape Research, vol. 38, Issue 6, 2013, pp. 750-767.

[23] Ho S., Rajabifard A., Kalantari M.: Invisible' constraints on 3D innovation in land administration: A case study on the city of Melbourne. Land Use Policy, vol. 42, 2015, pp. 412-425.

[24] Ho S., Rajabifard A., Stoter J., Kalantari M.: Legal barriers to 3D cadastre implementation: What is the issue?. Land Use Policy, vol. 35, 2013, pp. 379-387.

[25] Kalantari M., Dinsmore K., Urban-Karr J., Rajabifard A.: A roadmap to adopt the Land Administration Domain Model in cadastral information systems. Land Use Policy, vol. 49, 2015, pp. 552-564.

[26] Kanianska R., Kizekova M., Novacek J., Zeman M.: Land-use and land-cover changes in rural areas during different political systems: A case study of Slovakia from 1782 to 2006. Land Use Policy, vol. 36, 2014, pp. 554-566.

[27] Leitmanová M., Bažík J., Muchová Z.: New methods for gathering the spatial data from land consolidation project. Acta Scientiarum Polonorum. Formatio Circumiectus, vol. 14(1), 2015, pp. 125-133.

[28] Leń P., Oleniacz G., Skrzypczak I., Mika M.: The Hellwig's and Zero Unitarisation Methods in Creating a Ranking of the Urgency of Land Consolidation and Land Exchange Work. [in:] $16^{\text {th }}$ International Multidisciplinary Scientific GeoConference SGEM 2016, SGEM 2016 Conference Proceedings, Book 2, Vol. 2, 2016, pp. 617-624, DOI: 10.5593/SGEM2016/B22/S09.080.

[29] Lin Q.W., Kalantari M., Rajabifard A., Li J.F.: A path dependence perspective on the Chinese cadastral system. Land Use Policy, vol. 45, 2015, pp. 8-17.

[30] Lisec A., Navratil G.: The Austrian Land Cadastre: from the Earliest Beginnings to the Modern Land Information System. Geodetski Vestnik, vol. 58, Issue 3, 2014, pp. 482-516.

[31] Mivsek E., Ravnihar F., Znidarsic H.: Land Cadastre Plan Making. Geodetski Vestnik, vol. 56, Issue 4, 2012, pp. 691-697.

[32] Mourafetis G., Apostolopoulos K., Potsiou C., Ioannidis C.: Enhancing cadastral surveys by facilitating the participation of owners. Survey Review, vol. 4, Issue 344, 2015, pp. 316-324.

[33] Nizalov D., Ivinska K., Kubakh S.: Monitoring of land relations in Ukraine in 2014-2015: statist year-book. Kyiv School of Economics, 2015.

[34] Noszczyk T., Hernik J.: Modernization of the land and property register. Acta Scientiarum Polonorum. Formatio Circumiectus, vol. 15 (1), 2016, pp. 3-17.

[35] Pavliy A.S.: Analysis of land value taxation system in Ukraine. Scientific Herald of International Humanities University: science projects collection. Economics and Management, vol. 14, 2015, pp. 262-267. 
[36] Przewięźlikowska A., Buśko M.: The analysis of the updating time of subject and object data due to the information flow between the systems of the real estate cadastre and the land and mortgage register. [in:] SGEM 2014: GeoConference on Informatics, geoinformatics and remote sensing: $14^{\text {th }}$ international multidisciplinary scientific geoconference: 17-26 June, 2014, Albena, Bulgaria: conference proceedings. Vol. 3: Photogrammetry and remote sensing cartography and GIS, STEF92 Technology Ltd., Sofia, 2014, pp. 933-940.

[37] Santos J.C. dos, Farias E.S. de, Carneiro A.F.T.: Analysis of the parcel as a land unity of the Brazilian urban cadastre. Boletim de Ciencias Geodesicas, vol. 19, Issue 4, 2013, pp. 574-587.

[38] Skalos J., Molnarova K., Kottova P.: Land reforms reflected in the farming landscape in East Bohemia and in Southern Sweden: two faces of modernization. Applied Geography, vol. 35, Issue 1-2, 2012, pp. 114-123.

[39] Tax Code of Ukraine, 2010. [on-line:] http://zakon3.rada.gov.ua/laws/ show/2755-17 [access: 20.02.2017].

[40] The Act of 17 May 1989 Geodetic and Cartographic Law. Journal of Laws of 1989, No. 30, item 163 [Ustawa z dnia 17 maja 1989 r. Prawo geodezyjne $i$ kartograficzne. Dz.U. 1989, nr 30, poz. 163].

[41] The Regulation of the Minister of Regional Development and Construction of 29 March 2001 on land and buildings register. Journal of Laws of 2001, No. 38, item 454 [Rozporzadzenie Ministra Rozwoju Regionalnego i Budownictwa z dnia 29 marca 2001 r. w sprawie ewidencji gruntów i budynków. Dz.U. 2001, nr 38, poz. 454].

[42] The Regulation of the Council of Ministers of 17 January 2013 concerning integrated information system for real estate. Journal of Laws of 2013, item 249 [Rozporzadzenie Rady Ministrów z dnia 17 stycznia 2013 r. w sprawie zintegrowanego systemu informacji o nieruchomościach. Dz.U. 2013, poz. 249].

[43] Zwirowicz K.: Wybrane problemy ekonomiczno-techniczne wykorzystywania danych ewidencyjnych na potrzeby zwiazane z użytkowaniem ziemi. Studia i Materiały Towarzystwa Naukowego Nieruchomości, vol. 18 (4), 2010, pp. 67-76.

\section{Struktura użytkowania gruntów - analiza na przykładzie gmin wiejskich i miejskich w Polsce i na Ukrainie}

Streszczenie: $\mathrm{W}$ ostatnich latach $\mathrm{w}$ intensywny sposób prowadzone są na terenie Polski modernizacje ewidencji gruntów i budynków. W trakcie procedury związanej z modernizacją aktualizowane są między innymi dane o użytkach gruntowych. Oczywiście taka aktualizacja prowadzona jest również na bieżąco podczas geodezyjnych prac jednostkowych związanych z katastrem nieruchomości. W artykule została przedstawiona analiza zmian użytkowania gruntów na przykładzie gminy miejskiej oraz wiejskiej Polsce w latach 2002-2015 oraz sytuacja w tym aspekcie na Ukrainie. 
W analizowanym przedziale czasowym zostały przeprowadzone na testowym terenie dwie kompleksowe modernizacje katastru. Analiza dotyczyła dwóch użytków gruntowych: gruntów rolnych zabudowanych $(B r)$ oraz terenów mieszkaniowych $(B)$. Wybrane zostały te spośród wszystkich grup użytków, ponieważ w odniesieniu do nich zmieniały się w Polsce w sposób szczególny przepisy prawa regulujące zasady zaliczania użytku gruntowego do konkretnej grupy spośród wymienionych. Jednocześnie dla tych użytków przewidziane są skrajnie różne stawki podatku od nieruchomości. W opracowaniu została również przeprowadzona analiza zmian dochodów gmin pochodzących z opodatkowania właścicieli, spowodowana aktualizacją operatu katastralnego w zakresie zmian użytkowania gruntów.

\section{Słowa}

kluczowe: kataster, zmiany użytkowania gruntów, grunty rolne zabudowane, tereny mieszkaniowe, podatek od nieruchomości 